\title{
Transient Receptor Potential Melastatin 7 (TRPM7) Cation Channels, Magnesium and the Vascular System in Hypertension
}

\author{
Alvaro Yogi, PhD; Glaucia E. Callera, PhD; Tayze T. Antunes, PhD; \\ Rita C. Tostes, PhD; Rhian M. Touyz, MD, PhD
}

\begin{abstract}
Decreased $\mathrm{Mg}^{2+}$ concentration has been implicated in altered vascular reactivity, endothelial dysfunction and structural remodeling, processes important in vascular changes and target organ damage associated with hypertension. Unlike our knowledge of other major cations, mechanisms regulating cellular $\mathrm{Mg}^{2+}$ handling are poorly understood. Until recently little was known about protein transporters controlling transmembrane $\mathrm{Mg}^{2+}$ influx. However, new research has uncovered a number of genes and proteins identified as transmembrane $\mathrm{Mg}^{2+}$ transporters, particularly transient receptor potential melastatin (TRPM) cation channels, TRPM6 and TRPM7. Whereas TRPM6 is found primarily in epithelial cells, TRPM7 is ubiquitously expressed. Vascular TRPM7 has been implicated as a signaling kinase involved in vascular smooth muscle cell growth, apoptosis, adhesion, contraction, cytoskeletal organization and migration, and is modulated by vasoactive agents, pressure, stretch and osmotic changes. Emerging evidence suggests that vascular TRPM7 function might be altered in hypertension. The present review discusses the importance of $\mathrm{Mg}^{2+}$ in vascular biology in hypertension and focuses on transport systems, mainly TRPM7, that might play a role in the control of vascular $\mathrm{Mg}^{2+}$ homeostasis. Elucidation of the relationship between the complex systems responsible for regulation of $\mathrm{Mg}^{2+}$ homeostasis, the role of TRPM7 in vascular signaling, and the cardiovascular impact will be important for understanding the clinical implications of hypomagnesemia in cardiovascular disease. (Circ $J$ 2011; 75: 237-245)
\end{abstract}

Key Words: Cardiovascular system; Hypertension; Magnesium; TRPM7

$\mathbf{H}$ ypertension is the most common chronic disease in developed and developing societies and a major risk factor for morbidity and mortality. ${ }^{1,2}$ The most common form of hypertension is 'essential hypertension' the causes of which remain unknown. Among the many factors implicated in the pathophysiology of hypertension are neurohumoral, renal, metabolic, race, genetic, environmental factors and alterations in cellular cations, such as sodium $\left(\mathrm{Na}^{+}\right)$, calcium $\left(\mathrm{Ca}^{2+}\right)$, potassium $\left(\mathrm{K}^{+}\right)$and magnesium $\left(\mathrm{Mg}^{2+}\right)$ have been shown to be related to the increase in systolic blood pressure. ${ }^{3-7}$

$\mathrm{Mg}^{2+}$, an abundant intracellular divalent cation, functions as an allosteric modulator of several proteins, controls nucleotide and protein synthesis, regulates $\mathrm{Na}^{+}, \mathrm{K}^{+}$, and $\mathrm{Ca}^{2+}$ channels and is critical for myriad enzymatic reactions, particularly those involving kinases. ${ }^{8,9} \mathrm{Mg}^{2+}$ is stored primarily in bone and the intracellular compartments of muscle and soft tissues, with less than $1 \%$ of total body $\mathrm{Mg}^{2+}$ circulating in the blood. ${ }^{9,10} \mathrm{Mg}^{2+}$ homeostasis depends primarily on the balance between intestinal uptake and renal excretion. $\mathrm{Mg}^{2+}$ deficiency results from reduced dietary intake, intestinal malabsorption or renal loss. Mammalian cells tightly control magnesium levels within a narrow range $(0.70-1.1 \mathrm{mmol} / \mathrm{L})$ by specific regulatory mechanisms operating at the level of intraorganelle compartmentalization, intracellular magnesium buffering and at regulating magnesium entry and efflux across the cell membrane.

Epidemiological studies indicate that low $\mathrm{Mg}^{2+}$ status is associated with many diseases including diabetes, metabolic syndrome, dyslipidemia and hypertension. ${ }^{11-15}$ In the vascular system $\mathrm{Mg}^{2+}$ regulates vascular tone, cardiac rhythm and platelet-activated thrombosis. ${ }^{16,17}$ Increased intracellular $\mathrm{Mg}^{2+}$ concentration $\left(\left[\mathrm{Mg}^{2+}\right]_{\mathrm{i}}\right)$ causes vasodilation and attenuates agonist-induced vasoconstriction, whereas reduced $\left[\mathrm{Mg}^{2+}\right] \mathrm{i}$ has opposite effects, leading to hypercontractility and impaired vasorelaxation. ${ }^{18-21}$ Low $\left[\mathrm{Mg}^{2+}\right]$ i also results in abnormal vascular cell growth, inflammation and increased membrane permeability to $\mathrm{Na}^{+}$and $\mathrm{Ca}^{2+}$ accumulation in vascular smooth muscle cells (VSMC), which might be important in modulating vascular tone and function in hypertension.9,22

Although our understanding of renal and intestinal $\mathrm{Mg}^{2+}$ homeostasis has been greatly enhanced over the past few

Received October 24, 2010; accepted October 25, 2010; released online December 7, 2010

Kidney Research Center, Ottawa Hospital Research Institute, University of Ottawa, Ottawa (A.Y., G.E.C., T.T.A., R.M.T.), Canada; Medical School of Ribeirao Preto, University of Sao Paulo, Sao Paulo (R.C.T.), Brazil

Mailing address: Rhian M. Touyz, MD, PhD, Kidney Research Centre, Ottawa Hospital Research Institute, 451 Smyth Rd, Ottawa, ON,

KIH 8M5, Canada. E-mail: rtouyz@uottawa.ca

ISSN-1346-9843 doi:10.1253/circj.CJ-10-1021

All rights are reserved to the Japanese Circulation Society. For permissions, please e-mail: cj@j-circ.or.jp 
years there is still a paucity of information regarding the molecular mechanisms whereby cells regulate intracellular $\mathrm{Mg}^{2+}$ homeostasis and transport across membranes. Transporters and exchangers that have been implicated in transmembrane $\mathrm{Mg}^{2+}$ transport include, among others, the $\mathrm{Na}^{+} /$ $\mathrm{Mg}^{2+}$ exchanger, $\mathrm{Mg}^{2+} / \mathrm{Ca}^{2+}$ exchanger and the recently identified including transient receptor potential melastatin 6 and 7 channels (TRPM6, TRPM7). ${ }^{23-27}$ The present review will discuss the importance of $\mathrm{Mg}^{2+}$ in vascular biology in hypertension and will focus on the transport systems, mainly TRPM6/7, that might play a role in the control of vascular magnesium homeostasis.

\section{Cellular Mg Homeostasis}

Unlike our knowledge of other major cations, mechanisms regulating cellular $\mathrm{Mg}^{2+}$ handling are poorly understood. More than $95 \%$ of $\mathrm{Mg}^{2+}$ is sequestrated by chelators or bound to other biomolecules, including phospholipids, ribosomes and phosphonucleotides (ATP, ADP). ${ }^{9,26}$ Intracellular $\mathrm{Mg}^{2+}$ is maintained below the concentration predicted from the transmembrane electrochemical potential. This control is achieved through a balance of $\mathrm{Mg}^{2+}$ uptake, intracellular storage, and $\mathrm{Mg}^{2+}$ efflux mediated through specific $\mathrm{Mg}^{2+}$ transporters.

$\mathrm{Mg}^{2+}$ efflux occurs against the electrochemical gradient, therefore an energy-coupled mechanism for its extrusion must be present. $\mathrm{Mg}^{2+}$ efflux appears to be regulated by at least 2 pathways: the $\mathrm{Na}^{+}-\mathrm{Mg}^{2+}$ exchange driven by the $\mathrm{Na}^{+}$gradient, and the $\mathrm{Na}^{+}$-independent 'passive' $\mathrm{Mg}^{2+}$ transport via $\mathrm{Mg}^{2+}$-permeable channels. ${ }^{28,29} \mathrm{Na}^{+}$-dependent $\mathrm{Mg}^{2+}$ transport occurs mainly via the $\mathrm{Na}^{+} / \mathrm{Mg}^{2+}$ exchanger and has been demonstrated in many cell types, including VSMC and cardiomyocytes. ${ }^{30-32}$ However, $\mathrm{Na}^{+}$-independent transport, demonstrated mainly in erythrocytes and hepatic cells, involves $\mathrm{Ca}^{2+}\left(\mathrm{Ca}^{2+} / \mathrm{Mg}^{2+}\right.$ exchanger $), \mathrm{Mn}^{2+}\left(\mathrm{Mn}^{2+} / \mathrm{Mg}^{2+}\right.$ antiporter $)$ and $\mathrm{Cl}^{-}\left(\mathrm{Cl}^{-} / \mathrm{Mg}^{2+}\right.$ co-transporter $)$-dependent mechanisms. ${ }^{26,33-35}$ Regulation of these exchangers remain unclear, although Ang II, aldosterone, and other vasoactive agents have been shown to influence these transporters.

Until recently little was known about protein transporters controlling transmembrane magnesium influx. A few $\mathrm{Mg}^{2+}$ transporters had been demonstrated, but only at the biophysical and functional levels. Recent advances in the field have now identified specific transmembrane $\mathrm{Mg}^{2+}$ transporters. The first mammalian $\mathrm{Mg}^{2+}$ transporter to be identified at the molecular level was mitochondrial RNA splicing2 (Mrs2), responsible for mithocondrial $\mathrm{Mg}^{2+}$ uptake. ${ }^{36,37}$ Other proteins shown to regulate $\mathrm{Mg}^{2+}$ homeostasis include $\mathrm{Mg}^{2+}$ transporter subtype 1 (MagT1), the solute carrier (SLC) family 41 subtype 1 and 2 (SLC41A1, SLAC41A2, respectively) and the Ancient Conserved Domain Protein 2 (ACDP2). ${ }^{38-41}$ Recently it has been shown by microarray analysis that the NIPA1 and 2 genes, named for 'non-imprinted in Prader-Willi/Angelman', membrane $\mathrm{Mg}^{2+}$ transporters 1 and 2 (MMgT1 and 2 respectively) and Huntington interacting protein genes, HIP14 and HIP14L also encode a $\mathrm{Mg}^{2+}$ transporter. ${ }^{42-44}$

Analysis of different forms of human disorders characterized by low serum $\mathrm{Mg}^{2+}$ concentrations due to defective intestinal absorption and/or renal $\mathrm{Mg}^{2+}$ wasting led to the identification of a paracellular (between cells) magnesium transporter, paracellin-1 (claudin 16), a member of the claudin family of tight-junction proteins. ${ }^{45}$ Paracellin-1 mutations are associated with a hereditary disease, hypomagnesemia with hypercalciuria and nephrocalcinosis (FHHNC), characterized by massive renal $\mathrm{Mg}^{2+}$ and $\mathrm{Ca}^{2+}$ wasting leading to end-stage renal dis- ease. Genetic analyses of patients with primary hypomagnesemia and secondary hypocalcemia (HSH), another $\mathrm{Mg}^{2+}$-wasting disorder, identified TRPM6 (and its homologue TRPM7) as a key component of epithelial $\mathrm{Mg}^{2+}$ reabsorption..$^{46,47}$ The ubiquitously expressed TRPM7 was characterized functionally as a constitutively active ion channel permeable for divalent cations including $\mathrm{Mg}^{2+}$ and regulated by intracellular concentrations of $\mathrm{Mg}^{2+}$, magnesium-nucleotide complexes, and humoral factors. ${ }^{48,49}$

\section{TRPM Channels}

TRPM proteins, members of the transient receptor potential superfamily, possess 6 predicted transmembrane domains and display the structural hallmark of long intracellular NH2 and $\mathrm{COOH}$ termini. ${ }^{50-52}$ TRPM have been implicated in cardiovascular pathologies. ${ }^{52,53}$ The founding member, TRPM1 (melastatin), was detected in malignant melanoma cells. ${ }^{54}$ Members of the TRPM family are divided into 4 groups: ${ }^{51}$ TRPM1/3, TRPM2/8, TRPM4/5 and TRPM6/7. TRPM channels exhibit highly varying cation permeability, from $\mathrm{Ca}^{2+}$ impermeable (TRPM4/5) to highly $\mathrm{Ca}^{2+}$ and $\mathrm{Mg}^{2+}$ permeable (TRPM6 and TRPM7).

TRPM3, abundantly expressed in the kidney, are $\mathrm{Ca}^{2+}$-permeable ion channels activated by cell swelling. ${ }^{55,56}$ TRPM4 and TRPM5 are permeable to monovalent cations but impermeable to $\mathrm{Ca}^{2+}$ and display voltage-dependent modulation and rapid activation and deactivation kinetics on receptor stimulation and depolarization. TRPM4 exhibits the highest expression in heart, pancreas and placenta, whereas TRPM5 is enriched in taste receptor cells. ${ }^{57-59}$ A different role in sensory physiology has been ascribed to TRPM8, which is expressed in sensory neurons and prostate carcinoma cells and activated by menthol, icillin, and cool temperatures. TRPM8 acts as a plasmalemmal $\mathrm{Ca}^{2+}$ channel and as an intracellular $\mathrm{Ca}^{2+}$ release channel..$^{51,57,59}$

Three members of the TRPM family, TRPM2, TRPM6, and TRPM7, are set apart from other known ion channels because they harbor enzyme domains in their respective $\mathrm{COOH}$ termini and thus represent prototypes of an intriguing new protein family of enzyme-coupled ion channels termed 'chanzyme' (channel plus enzyme). ${ }^{25,50,51,60}$ TRPM2 is expressed mainly in the brain and is a non-selective cation channel permeable to $\mathrm{Na}^{+}, \mathrm{Ca}^{2+}, \mathrm{K}^{+}$and $\mathrm{Cs}^{+}$. TRPM2 is $\mathrm{COOH}$ terminally fused to an ADP-pyrophosphatase and is activated by one of the products of NAD hydrolysis, ADP-ribose. ${ }^{61}$ TRPM2 is highly sensitivity to $\mathrm{H}_{2} \mathrm{O}_{2}$ and other reactive oxygen species. ${ }^{62}$

TRPM6 and TRPM7 are now well accepted as important regulators of $\mathrm{Mg}^{2+}$ homeostasis. These channels also transport other cations such as $\mathrm{Ca}^{2+}, \mathrm{Zn}^{2+}, \mathrm{Mn}^{2+}$, and $\mathrm{Co}^{2+}$ and in the absence of $\mathrm{Ca}^{2+}$ and $\mathrm{Mg}^{2+}$ they can mediate $\mathrm{Na}^{+}$flux. ${ }^{27,63,64}$ TRPM6 and TRPM7 share $\sim 50 \%$ sequence homology, are constitutively active and contain protein kinase domains in their $\mathrm{COOH}$ termini, which bear sequence similarity to elongation factor 2 (eEF-2) serine/threonine kinases. ${ }^{49}$

TRPM6 mRNA shows a restricted expression pattern, with the highest levels along the intestine and the distal convoluted tubule (DCT) of the kidney. TRPM6 co-localizes with cytosolic proteins that buffer intracellular $\mathrm{Mg}^{2+}$ such as $\mathrm{Na}^{+} / \mathrm{Cl}^{-}$cotransporter NCCT, parvalbumin and calbindinD28K. ${ }^{46,47,65-67}$ The critical role of TRPM6 for epithelial $\mathrm{Mg}^{2+}$ transport became evident when positional cloning showed that $\mathrm{HSH}$, an autosomal-recessive disorder and characterized by low serum $\mathrm{Mg}^{2+}$ concentrations due to diminished intestinal $\mathrm{Mg}^{2+}$ absorption and decreased renal $\mathrm{Mg}^{2+}$ reabsorption, is 


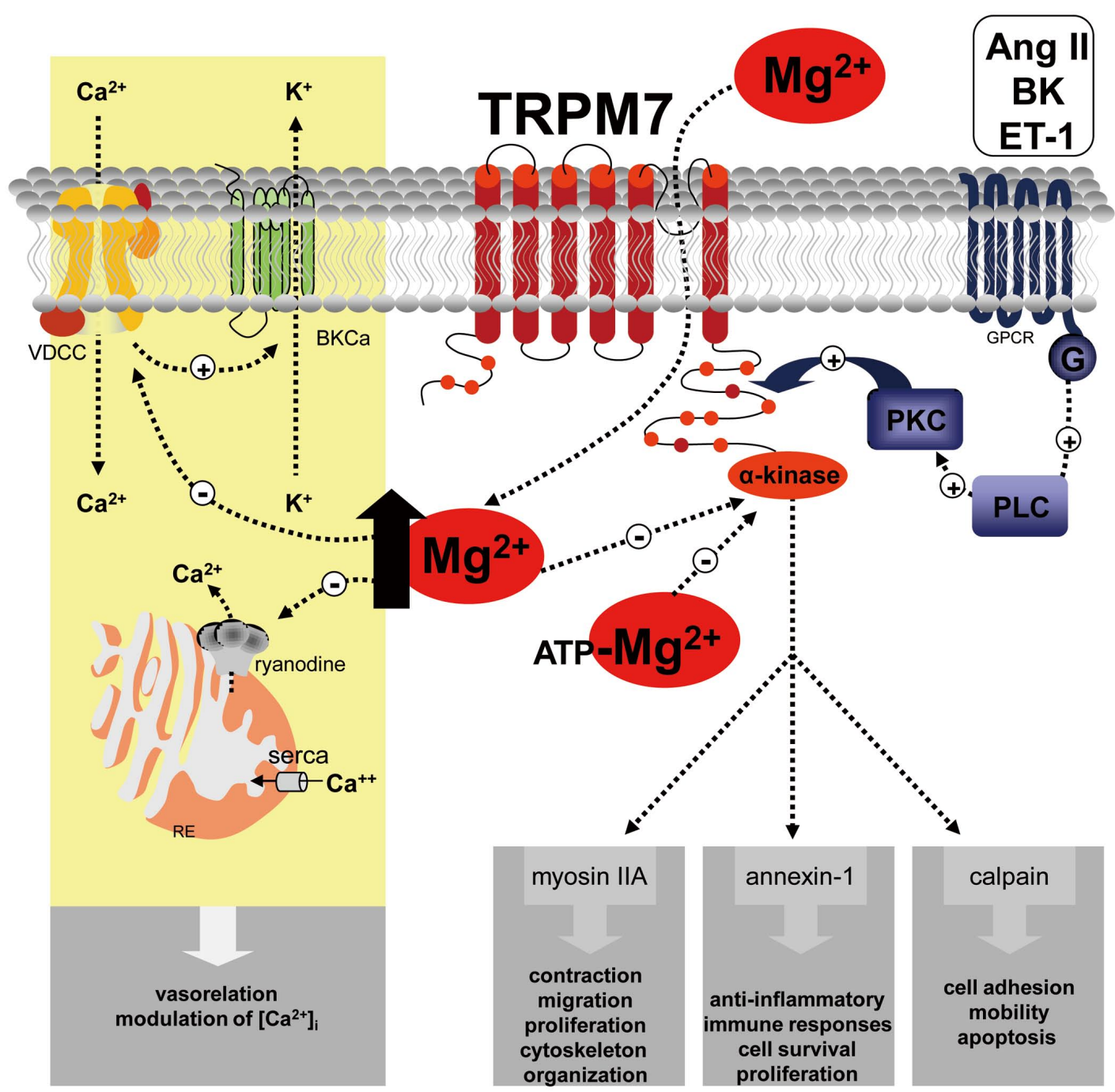

Figure 1. $\mathrm{Mg}^{2+}$ regulation and cell signaling by transient receptor potential melastatin 7 (TRPM7). The dual ability of TRPM7 to act as an ion channel and as a kinase, suggests that this protein is involved in regulating both cellular $\mathrm{Mg}^{2+}$ status and intracellular signaling. Three known TRPM7 kinase substrates have been identified, annexin-1, myosin IIA heavy chain and calpain, which are involved in anti-inflammatory responses, growth, contraction and apoptosis.

caused by mutations in the TRPM6 gene. ${ }^{46,47,66}$ Factors implicated in TRPM6 regulation remain unclear, but $17 \beta$-estradiol and $\mathrm{Mg}^{2+}$ are important, ${ }^{68}$ TRPM6 currents are inhibited by millimolar concentrations of intracellular $\mathrm{Mg}^{2+}{ }^{64,65,67}$ Recent studies identified epidermal growth factor (EGF) as an autocrine/paracrine magnesiotropic hormone. EGF binding to its EGFR at the basolateral membrane of the DCT and stimulates endomembrane trafficking and increased number of TRPM6 channels at the plasma membrane. ${ }^{69,70}$ The signaling pathway downstream of EGFR activation, which stimulates TRPM6-mediated $\mathrm{Mg}^{2+}$ influx is dependent on Src, ERK/ MEK, PI3K and AP-1..$^{70,71}$ The role of EGFR signaling in $\mathrm{Mg}^{2+}$ homeostasis is further supported by the observation that patients treated with cetuximab, a mAb directed against the EGFR, develop hypomagnesemia. ${ }^{72,73}$

To date little is known about the TRPM6 $\alpha$-kinase domain. Receptor for activated C-kinase 1 and repressor of estrogen receptor activity interact with the $\alpha$-kinase domain and inhibit channel activity in a phosphorylation-dependent manner. ${ }^{74}$ Intracellular ATP modulation of TRPM6 channel activity requires the ATP-binding motif in the $\alpha$-kinase domain. Also, the $\alpha$-kinase of TRPM6 is capable of phosphorylating TRPM7 but not vice versa, underlying the functional non-redundancy of these 2 chanzymes. ${ }^{25}$

TRPM6 and TRPM7 can form hetero-oligomeric channel complexes. TRPM7 but not other members of the TRPM family seems to be necessary for TRPM6 trafficking to the plasma membrane..$^{23,25,27,66}$ TRPM7 is functional on its own, but homo-oligomerization might be needed for correct positioning of TRPM7 to the plasma membrane. ${ }^{23,25}$ Single-channel conductance and biophysical properties studies suggest that TRPM6, TRPM7 and the complex TRPM6/7 are distinct ion channels that exhibit different divalent cation permeability, $\mathrm{pH}$ sensitivity and unique single channel conductance..$^{75}$ Also, TRPM6 and TRPM7 have distinct properties with respect to the pharmacological agent 2-aminoethoxydiphenyl 
borate (2-APB). Whereas micromolar levels of 2-APB maximally increase TRPM6 activity, they inhibit activity of TRPM7 channels. ${ }^{75}$ The exact role of TRPM6/TRPM7 complex in $\mathrm{Mg}^{2+}$ homeostasis remains to be elucidated.

\section{TRPM7}

TRPM7 is ubiquitously expressed. ${ }^{48,49}$ In physiological conditions TRPM7 preferentially transports $\mathrm{Mg}^{2+}$ and to a lesser extent $\mathrm{Ca}^{2+}$ and other divalent cations. Because $\mathrm{Mg}^{2+}$ plays such an important role in cell function, it seems unlikely that TRPM7 is the only transporter involved in maintaining intracellular $\mathrm{Mg}^{2+}$ concentration. In support of this, a recent study using primary mammalian cells found that deletion of TRPM7 did not alter cellular $\mathrm{Mg}^{2+}$ concentration. ${ }^{76}$ Several other studies demonstrated that targeted disruption of TRPM7 gene in cell lines is lethal, underpinning a salient and non-redundant role of this channel in cell physiology and cell survival. ${ }^{23,48}$

TRPM7 is constitutively active and like TRPM6 is negatively regulated by changes in cytosolic $\mathrm{Mg}^{2+}$ or $\mathrm{Mg}^{2+}$ ATP. ${ }^{23,25,48,49,63,77}$ Several studies have demonstrated that ATP acts as an intracellular $\mathrm{Mg}^{2+}$ chelator, decreasing the concentration of intracellular free $\mathrm{Mg}^{2+}$, leading to increased TRPM7mediated conductance.

The functional $\alpha$-kinase domain at the carboxyl terminus of TRPM7 has been structurally characterized by X-ray crystallography and displays the unique features of a zinc finger domain as well as a region involved in the catalysis of ATPtriggered reactions. ${ }^{78}$ The dual ability of TRPM7 to act as a channel and at the same time as a kinase, suggests that this protein is involved in regulating both cellular $\mathrm{Mg}^{2+}$ status and intracellular signaling. ${ }^{48,49}$ The role of TRPM7 kinase domain for the channel function is still controversial. While some studies reported that phosphotransferase-deficient TRPM7 mutants displayed reduced sensitivity for intracellular $\mathrm{Mg}^{2+}$ and reduced current amplitude upon $\mathrm{G}$ protein-coupled receptor stimulation or were even not functional, others found no changes in $\mathrm{Mg}^{2+}$ sensitivity of TRPM7 channels lacking the $\alpha$-kinase domain when compared to wild-type channel. ${ }^{23,48,49,80}$ Since the $\alpha$-kinase is adjacent to the conducting pore of TRPM7, changes in free $\mathrm{Mg}^{2+}$ concentrations might activate the associated kinase domain. The kinase in turn would signal via other phosphorylated substrates and/or feedback to modulate TRPM7 channel gating. Thus TRPM7 could function as a ' $\mathrm{Mg}^{2+}$ sensor'. ${ }^{25-27,48,49,79,80}$ It is also possible that the kinase domain might play a role in channel assembly or subcellular localization to the plasma membrane (Figure 1).

To date, 3 known TRPM7 kinase substrates have been identified, annexin-1, myosin IIA heavy chain and calpain. ${ }^{81-83}$ Annexin-1 is an endogenous mediator of the anti-inflammatory actions of glucocorticoids, and is implicated in cell growth and apoptosis. ${ }^{81}$ Considering that both annexin- 1 and TRPM7 have been linked to processes of cell survival and cell growth it is possible that the regulation of cell death and proliferation by TRPM7 involves phosphorylation of annexin-1 by TRPM7 kinase. Myosin II heavy chain is involved in cell migration, growth, apoptosis and cytoskeletal organization. Identification of myosin IIA heavy chain as another substract for TRPM7 $\alpha$-kinase domain further supported the role of this channel in cell growth and differentiation. ${ }^{82}$ TRPM7 also activates calpain and initiates the disassembly or turnover of peripheral adhesion complexes, which is involved in cell adhesion, motility, metastasis, apoptosis, and ischemic cell death. In fact, after neural injury, TRPM7 might accelerate the anoxia-induced production of reactive oxygen species and exacerbate cell death. ${ }^{84}$ Other possible functions of the kinase domain include a role in phospholipase signaling. ${ }^{49,85}$ The biological significance of TRPM7-regulated downstream targets still remains unclear, because studies on these substrates were performed mainly in cell lines.

\section{TRPM7, $\mathrm{Mg}^{2+}$ and Hypertension}

Epidemiological studies have linked the prevalence of cardiovascular diseases, including hypertension, and the quality of drinking water or diet. Among the many factors studied in drinking water, the highest inverse correlation has been observed between $\mathrm{Mg}^{2+}$ and cardiovascular mortality and morbidity, ${ }^{86}$ and later by other epidemiological and clinical investigations that supported the hypothesis that increased $\mathrm{Mg}^{2+}$ intake contributes to prevention of hypertension and cardiovascular disease. ${ }^{87-89}$

Magnesium supplementation has been shown to lower blood pressure in some experimental models of hypertension. ${ }^{90,91}$ Clinical studies have shown increased, decreased and no effect of $\mathrm{Mg}^{2+}$ depletion or supplementation in hypertension. Despite these inconsistencies there are some groups of hypertensive patients who consistently demonstrate altered $\mathrm{Mg}^{2+}$ metabolism. These include individuals of African descent, obese participants, patients with severe or malignant forms of hypertension, elderly patients and those with metabolic syndrome. ${ }^{92,93}$ Such hypertensive patients might be $\mathrm{Mg}^{2+}$ sensitive and potentially could benefit from $\mathrm{Mg}^{2+}$ supplementation.

Blood pressure is regulated by a variety of $\mathrm{Mg}^{2+}$-sensitive factors that influence systemic vascular tone and resistance. ${ }^{94,95}$ Ion channels, which are essential for the control of membrane potential and thus vascular tone are modulated by changes in intracellular $\mathrm{Mg}^{2+}$. Increased $\left[\mathrm{Mg}^{2+}\right]_{i}$ suppresses voltagedependent $\mathrm{Ca}^{2+}$ channels (VDCC), directly blocks inward rectifier $\mathrm{K}^{+}$channels, and stimulates large conductance $\mathrm{Ca}^{2+}$ activated $\mathrm{K}^{+}(\mathrm{BKCa})$ channels. ${ }^{96} \mathrm{Ca}^{2+}$, a major determinant of cell contraction, proliferation, migration and secretion, is negatively modulated by $\mathrm{Mg}^{2+}$. Magnesium inhibits $\mathrm{Ca}^{2+}$ depolarizing effects, $\mathrm{Ca}^{2+}$-related excitation-contraction coupling, and also acts as a weak $\mathrm{Ca}^{2+}$ channel blocker promoting vasorelaxation. ${ }^{97}$ The endothelium has also been shown to play a functional role in the regulation of vasomotor tone by generating and releasing endothelium-derived relaxing factors. $\mathrm{Mg}^{2+}$ promotes vasodilation through nitric oxide-dependent pathways and by cyclo-oxygenase-dependent mechanisms, via production of prostacyclin (PGI2) in isolated aorta from rats. ${ }^{98,99}$ Magnesium-mediated endothelial release of PGI2 from human umbilical arteries and cultured umbilical vein endothelial cells might be particularly relevant in $\mathrm{MgSO}_{4}$ treatment of eclampsia and pre-eclampsia. ${ }^{99,100}$

Magnesium also alters responses to vasoconstrictor and vasodilator agents. Absence of $\mathrm{Mg}^{2+}$ significantly potentiates contractile responses of vessels to bradykinin, Ang II, serotonin and prostaglandin F $2 \alpha$. These effects might be related to altered binding of agonists to their specific cell membrane receptors and/or to production of vasoactive agents. ${ }^{99,101}$ Magnesium infusion also inhibits endothelin-1-induced vasoconstriction and high extracellular $\mathrm{Mg}^{2+}$ concentration reduces the affinity of endothelin- 1 for its specific receptors. ${ }^{101}$ Furthermore, in magnesium-deficient rats, plasma ET-1 levels are elevated, whereas in magnesium-supplemented rats, plasma ET-1 levels are reduced. ${ }^{94,101}$

Another possible mechanism whereby $\mathrm{Mg}^{2+}$ could have an impact on vascular function is via its antioxidant, anti- 


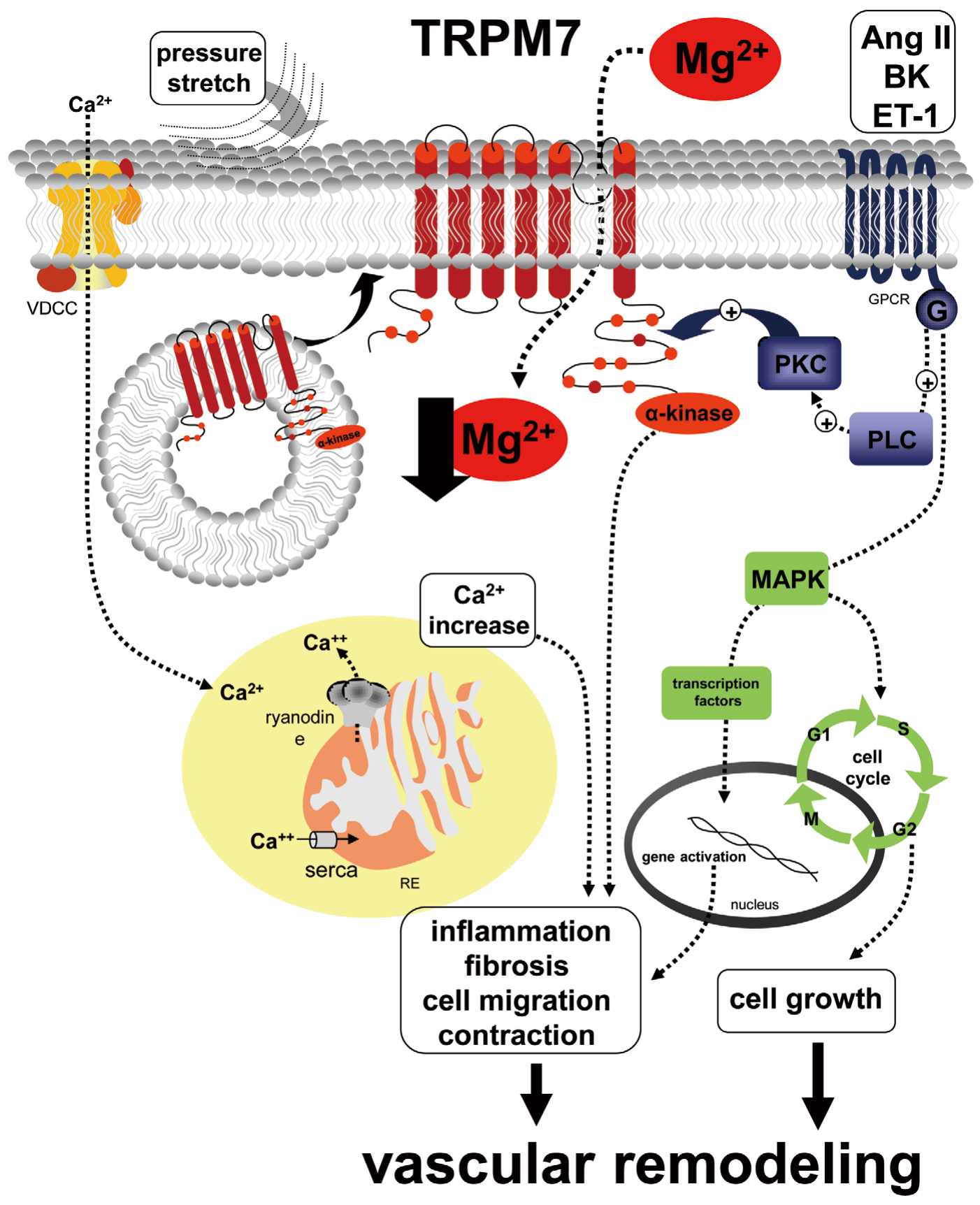

Figure 2. TRPM7 have been implicated in a number of vascular pathologies, including hypertension. Ang II, bradikinin (BK) and ET-1 regulate vascular transient receptor potential melastatin 7 (TRPM7) acutely by inducing phosphorylation and chronically by increasing expression at the mRNA and protein levels. Fluid flow and shear stress stimulate TRPM7 cytosol-to-membrane translocation in vascular smooth muscle cell (VSMC) and the amplitude of a native TRPM7-like current. These observations suggest that TRPM7 might also act as a mechanotransducer. Altered cellular Mg²+ homeostasis and abnormal VSMC function in hypertension might be related to defective TRPM7 expression/activity, which could contribute to proliferation, inflammation, fibrosis and contraction, important in vascular remodeling associated with high blood pressure.

inflammatory and growth-regulatory properties. ${ }^{102,103} \mathrm{Mg}^{2+}$ has antioxidant/anti-inflammatory properties scavenging oxygen radicals possibly by the spontaneous dismutation of superoxide anions $\left(\cdot \mathrm{O}_{2}{ }^{-}\right)$. Magnesium is also an essential requirement for the synthesis of some important natural antioxidants that could attenuate damaging actions of oxidative stress and inflammation in the vasculature. ${ }^{102,103}$ In fact, $\mathrm{Mg}^{2+}$ deficiency enhanced oxidative damage, increased plasma concentrations of lipoproteins and induced oxidative damage to erythrocytes, neuronal and vascular cells. ${ }^{102-104}$ Increased production of $\cdot \mathrm{O}_{2}{ }^{-}$and hydrogen peroxide $\left(\mathrm{H}_{2} \mathrm{O}_{2}\right)$ provoked by reduced $\mathrm{Mg}^{2+}$ concentrations, is associated not only with contraction, 
hypertrophy and hyperplasia of VSMC but also with inflammatory responses and subsequent tissue injury. ${ }^{102-106}$

Underlying mechanisms for altered magnesium homeostasis in hypertension are unclear, but inborn errors of $\mathrm{Mg}^{2+}$ handling, decreased membrane permeability, altered $\mathrm{Na}^{+} / \mathrm{Mg}^{2+}$ exchange, defective membrane binding and impaired cellular responsiveness have been implicated. ${ }^{107} \mathrm{We}$ and others showed that the $\mathrm{Na}^{+} / \mathrm{Mg}^{2+}$ antiport function, which plays a major role in $\mathrm{Mg}^{2+}$ extrusion in cardiac, renal and VSMC, is altered in hypertension. ${ }^{108-111}$ Furthermore, amiloride and quinidine-mediated inhibition of $\mathrm{Na}^{+} / \mathrm{Mg}^{2+}$ antiport increased vascular $\left[\mathrm{Mg}^{2+}\right]_{i}$ and attenuated the development of hypertension in SHR. ${ }^{104-111}$ Also, in Ang II-induced hypertension in rats, inhibition of the $\mathrm{Na}^{+} / \mathrm{Mg}^{2+}$ antiport resulted in reduced blood pressure, normalization of vascular and renal MAP kinase activity and improved vascular structure. ${ }^{104-111}$

TRPM6 and TRPM7 have been implicated in a number of vascular pathologies, including endothelial dysfunction and hypertension. ${ }^{112,113} \mathrm{We}$ and others demonstrated that VSMC from mouse, rat and human resistance arteries possess TRPM6 and TRPM7 cation channels and that TRPM7 is critically involved in regulating $\mathrm{Mg}^{2+}$ influx, cell viability, proliferation and contraction/dilation. ${ }^{47,67,114,115}$ Fluid flow and fluid-induced shear stress stimulates cytosol-to-membrane translocation of TRPM7 in VSMC and the amplitude of a native TRPM7-like current. ${ }^{116}$ These observations suggest that TRPM7 might act as a mechanotransducer, which could be important in pathological responses to vessel wall injury, particularly in the context of endothelial damage. Ang II and aldosterone, important vasoactive agents, regulate vascular TRPM7 acutely by inducing phosphorylation and chronically by increasing expression at the mRNA and protein levels. ${ }^{114,115}$ We recently identified a novel signaling pathway whereby bradykinin, through TRPM7, also influence proinflammatory responses in VSMC. ${ }^{117}$ Also, downregulation of vascular TRPM7 by siRNA reduced basal $\left[\mathrm{Mg}^{2+}\right]_{\mathrm{i}}$ and Ang II-stimulated $\left[\mathrm{Mg}^{2+}\right]$ i transients and attenuated Ang II-mediated VSMC growth. These findings confirmed that TRPM7 is a key regulator of magnesium homeostasis and that it plays a major role in vascular cell function (Figure 2).

In the context of high blood pressure, we showed that reduced $\mathrm{Mg}^{2+}$ influx in VSMC in SHR was associated with downregulation of vascular TRPM7, but not of TRPM6. ${ }^{115}$ Also, Ang II-mediated TRPM7, but not TRPM6, expression and activity were attenuated in hypertensive rats suggesting that altered regulation of $\mathrm{Mg}^{2+}$ in VSMC involve TRPM7dependent mechanisms. ${ }^{115}$ In SHR, aldosterone-infused mice and other experimental models of hypertension, TRPM7 is downregulated and this is associated with altered VSMC $\mathrm{Mg}^{2+}$ transport, decreased $\left[\mathrm{Mg}^{2+}\right] \mathrm{i}$ and impaired vasodilation. ${ }^{114-120}$ These data suggest that altered cellular $\mathrm{Mg}^{2+}$ homeostasis and abnormal VSMC function in hypertension might be related to defective TRPM7 expression/activity, which could contribute to proliferation, inflammation, fibrosis and contraction, important in processes involved in vascular remodeling associated with high blood pressure (Figure 2).

To further explore the pathophysiological significance of TRPM channels and vascular damage, we used a model of inherited hypomagnesemia to investigate effects of chronic $\mathrm{Mg}^{2+}$ deficiency on the cardiovascular system. Using bidirectional selective breeding, mice from a heterogenous population mice were selected for low $(\mathrm{MgL})$ and normal-high $(\mathrm{MgH})$ levels of erythrocyte magnesium. MgL mice demonstrate inherited hypomagnesemia, with significant reductions in plasma, bone, and kidney magnesium concentrations. ${ }^{121}$ In- bred mice with intracellular $\mathrm{Mg}^{2+}$ deficiency exhibit increased systolic blood pressure, impaired endothelial function, outward hypertrophic remodeling of arteries and vascular inflammation. We also reported altered vascular TRPM7 and annexin-1 expression, thus, identifying a vascular phenotype associated with magnesium deficiency and highlighting an important role for magnesium and TRPM7 in the maintenance of vascular integrity and function. ${ }^{113}$

Clinically, there are a number of well-defined conditions in which high blood pressure is associated with hypomagnesemia, including hyperaldosteronism, use of diuretics in the management of hypertension and congestive cardiac failure and treatment with calcineurin inhibitors as immunosuppressive drugs. ${ }^{122,123}$ Hyperaldosteronism is associated not only with increased systolic blood pressure but also with electrolyte imbalances, including hypomagnesemia, ${ }^{124,125}$ possibly through modulation of TRPM6/TRPM7.115,116 In patients with congestive cardiac failure and hyperaldosteronism, spironolactone, a mineralocorticoid receptor blocker, improved arrythmias and prevented intraerythrocyte $\mathrm{Mg}^{2+}$ depletion, ${ }^{126}$ possibly through effects on cellular $\mathrm{Mg}^{2+}$ transport systems as we showed in experimental models. ${ }^{115,116}$

\section{Conclusions}

Inadequate magnesium intake and hypomagnesemia might contribute to the pathophysiology of chronic diseases, such as hypertension. Magnesium normally regulates vascular tone and reactivity by modulating $\mathrm{Na}^{+}, \mathrm{K}^{+}$and $\mathrm{Ca}^{2+}$ and by influencing activity of multiple enzymes. Several studies have demonstrated that magnesium plays an important role in the maintenance of vascular integrity, where decreased $\mathrm{Mg}^{2+}$ content is associated with endothelial dysfunction, increased reactivity, enhanced contractility, vascular remodeling and inflammation and elevated blood pressure. However, increased vascular $\mathrm{Mg}^{2+}$ concentrations are associated with vasodilation, anti-inflammatory responses and reduced blood pressure. Unlike our knowledge of other major cations, cellular $\mathrm{Mg}^{2+}$ handling is poorly understood and until recently little was known about pathways regulating $\mathrm{Mg}^{2+}$ transport. To date, a number of $\mathrm{Mg}^{2+}$ efflux pathways, including the $\mathrm{Na}^{+} / \mathrm{Mg}^{2+}$ antiporter and the $\mathrm{Ca}^{2+} / \mathrm{Mg}^{2+}$ exchanger, have been demonstrated at a functional level. Recently TRPM6 and TRPM7 have been identified as unique $\mathrm{Mg}^{2+}$ transporters regulating $\mathrm{Mg}^{2+}$ influx. Vascular TRPM7 expression/activity appears to be altered in experimental models of hypertension. Such aberrations might contribute to $\mathrm{Mg}^{2+}$ dysregulation and vascular dysfunction associated with high blood pressure. There is still much to be discovered regarding the function and regulation of TRPM6, TRPM7 and TRPM6/7 and of the importance of these channels in cardiovascular biology in health and disease.

\section{References}

1. Wolf-Maier K, Cooper RS, Banegas JR, Giampaoli S, Hense $\mathrm{HW}$, Joffres M, et al. Hypertension prevalence and blood pressure levels in 6 European countries, Canada, and the United States. JAMA 2003; 289: 2363-2369.

2. Anderson GF, Chu E. Expanding priorities-confronting chronic disease in countries with low income. $N$ Engl J Med 2007; 356: 209-211.

3. Resnick LM, Laragh JH, Sealey JE, Alderman MH. Divalent cations in essential hypertension: Relations between serum ionized calcium, magnesium, and plasma rennin activity. $N$ Engl J Med 1983; 309: 888-891.

4. Resnick LM, Gupta RK, Bhargava KK, Gruenspan H, Alderman $\mathrm{MH}$, Laragh JH. Cellular ions in hypertension, diabetes, and obesity: A nuclear magnetic resonance spectroscopic study. Hyper- 
tension 1991; 17: 951-957

5. Resnick LM. Cellular calcium and magnesium metabolism in the pathophysiology and treatment of hypertension and related metabolic disorders. Am J Med 1992; 93: 11S-20S.

6. Aviv A. Salt consumption, reactive oxygen species and cardiovascular ageing: A hypothetical link. J Hypertens 2002; 20: $555-$ 559.

7. Schiffrin EL, Touyz RM. From bedside to bench to bedside: Role of reninangiotensin-aldosterone system in remodeling of resistance arteries in hypertension. Am J Physiol Heart Circ Physiol 2004; 287: $\mathrm{H} 435-\mathrm{H} 446$

8. Wolf FI, Cittadini A. Magnesium in cell proliferation and differentiation. Front Biosci 1999; 4: D607-D617.

9. Rubin H. The logic of the Membrane, Magnesium, Mitosis (MMM) model for the regulation of animal cell proliferation. Arch Biochem Biophys 2007; 458: 16-23.

10. Fox C, Ramsoomair D, Carter C. Magnesium: Its proven and potential clinical significance. South Med J 2001; 94: 1195-1201.

11. Nozue T, Kobayashi A, Uemasu F, Takagi Y, Sako A, Endoh H Magnesium status, serum HDL cholesterol, and apolipoprotein A-1 levels. J Pediatr Gastroenterol Nutr 1995; 20: 316-318.

12. Guerrero-Romero F, Rodriguez-Moran M. Low serum magnesium levels and metabolic syndrome. Acta Diabetol 2002; 39: 209213.

13. Swaminathan R. Magnesium metabolism and its disorders. Clin Biochem Rev 2003; 24: 47-66.

14. Barbagallo M, Dominguez LJ. Magnesium metabolism in type 2 diabetes mellitus, metabolic syndrome and insulin resistance. Arch Biochem Biophys 2007; 458: 40-47.

15. Sontia B, Touyz RM. Magnesium transport in hypertension. Pathophysiology 2007; 14: 205-211.

16. Altura BM, Altura BT. New perspectives on the role of magnesium in the pathophysiology of the cardiovascular system. II: Experimental aspects. Magnesium 1985; 4: 245-271.

17. Shechter M, Merz CN, Paul-Labrador M, Meisel SR, Rude RK, Molloy MD, et al. Oral magnesium supplementation inhibits platelet-dependent thrombosis in patients with coronary artery disease. Am J Cardiol 1999; 84: 152-156.

18. Laurant P, Touyz RM, Schiffrin EL. Effect of magnesium on vascular tone and reactivity in pressurized mesenteric resistance arteries from spontaneously hypertensive rats. Can J Physiol Pharmacol 1997; 75: 293-300.

19. Touyz RM, Laurant P, Schiffrin EL. Effect of magnesium on calcium responses to vasopressin in vascular smooth muscle cells of spontaneously hypertensive rats. J Pharmacol Exp Ther 1998; 284: $998-1005$

20. Yang ZW, Wang J, Zheng T, Altura BT, Altura BM. Low $\left[\mathrm{Mg}^{2+}\right]_{\mathrm{o}}$ induces contraction and $\left[\mathrm{Ca}^{2+}\right]$ i rises in cerebral arteries: Roles of $\mathrm{Ca}^{2+}$, PKC, and PI3. Am J Physiol Heart Circ Physiol 2000; 279: $\mathrm{H} 2898-\mathrm{H} 2907$.

21. Northcott CA, Watts SW. Low $\left[\mathrm{Mg}^{2+}\right]_{e}$ enhances arterial spontaneous tone via phosphatidylinositol 3-kinase in DOCA-salt hypertension. Hypertension 2004; 43: 125-129.

22. Yoshimura M, Oshima T, Matsuura H, Ishida T, Kambe M, Kajiyama G. Extracellular $\mathrm{Mg}^{2+}$ inhibits capacitance $\mathrm{Ca}^{2+}$ entry in vascular smooth muscle cells. Circulation 1997; 95: 2567-2572.

23. Schmitz C, Perraud AL, Johnson CO, Inabe K, Smith MK, Penner $\mathrm{R}$, et al. Regulation of vertebrate cellular $\mathrm{Mg} 2+$ homeostasis by TRPM7. Cell 2003; 114: 191-200.

24. Zoller MK, Hermosura MC, Nadler MJ, Scharenberg AM, Penner R, Fleig A. TRPM7 provides an ion channel mechanism for cellular entry of trace metal ions. J Gen Physiol 2003; 121: 49-60.

25. Schmitz C, Dorovkov MV, Zhao X, Davenport BJ, Ryazanov AG, Perraud AL. The channel kinases TRPM6 and TRPM7 are functionally nonredundant. J Biol Chem 2005; 280: 37763-37771.

26. Romani AM. Regulation of magnesium homeostasis and transport in mammalian cells. Arch Biochem Biophys 2007; 458: 90-102.

27. Schlingmann KP, Waldegger S, Konrad M, Chubanov V, Gudermann T. TRPM6 and TRPM7: Gatekeepers of human magnesium metabolism. Biochim Biophys Acta 2007; 1772: 813-821.

28. Flatman PW, Smith LM. Magnesium transport in ferret red cells. J Physiol 1990; 431: 11-25.

29. Handy RD, Gow IF, Ellis D, Flatman PW. $\mathrm{Na}^{+}$-dependent regulation of intracellular free magnesium concentration in isolated rat ventricular myocytes. J Mol Cell Cardiol 1996; 28: 1641-1651.

30. Okada K, Ishikawa S, Saito T. Cellular mechanisms of vasopressin and endothelin to mobilize [Mg2+]i in vascular smooth muscle cells. Am J Physiol 1992; 263: C873-C878.

31. Fagan TE, Romani A. Activation of $\mathrm{Na}(+)-$ and $\mathrm{Ca}(2+)$-dependent $\operatorname{Mg}(2+)$ extrusion by alpha(1)- and beta-adrenergic agonists in rat liver cells. Am J Physiol Gastrointest Liver Physiol 2000; 279: G943-G950

32. Romani AM, Maguire ME. Hormonal regulation of $\mathrm{Mg} 2+$ transport and homeostasis in eukaryotic cells. Biometals 2002; 15: $271-283$

33. Almulla HA, Bush PG, Steele MG, Ellis D, Flatman PW. Loading rat heart myocytes with $\mathrm{Mg} 2+$ using low-[Na+] solutions. J Physiol 2006; 575: 443-454.

34. Gunther T. Mechanisms, regulation and pathologic significance of Mg2+ efflux from erythrocytes. Magnes Res 2006; 19: 190-198.

35. Cefaratti C, Romani AM. Functional characterization of two distinct $\mathrm{Mg}(2+)$ extrusion mechanisms in cardiac sarcolemmal vesicles. Mol Cell Biochem 2007; 303: 63-72.

36. Bui DM, Gregan J, Jarosch E, Ragnini A, Schweyen RJ. The bacterial magnesium transporter CorA can functionally substitute for its putative homologue Mrs2p in the yeast inner mitochondrial membrane. J Biol Chem 1999; 274: 20438-20443.

37. Kolisek M, Zsurka G, Samaj J, Weghuber J, Schweyen RJ, Schweigel M. Mrs2p is an essential component of the major electrophoretic $\mathrm{Mg} 2+$ influx system in mitochondria. EMBO J 2003; 22: $1235-1244$.

38. Goytain A, Quamme GA. Identification and characterization of a novel mammalian $\mathrm{Mg} 2+$ transporter with channel-like properties. BMC Genomics 2005; 6: 48.

39. Goytain A, Quamme GA. Functional characterization of human SLC41A1, a Mg2 + transporter with similarity to prokaryotic MgtE $\mathrm{Mg} 2+$ transporters. Physiol Genomics 2005; 21: 337-342.

40. Goytain A, Quamme GA. Functional characterization of ACDP2 (ancient conserved domain protein), a divalent metal transporter. Physiol Genomics 2005; 22: 382-389.

41. Sahni J, Nelson B, Scharenberg AM. SLC41A2 encodes a plasmamembrane Mg2+ transporter. Biochem J 2007; 401: 505-513.

42. Goytain A, Hines RM, El-Husseini A, Quamme GA. NIPA1 (SPG6), the basis for autosomal dominant form of hereditary spastic paraplegia encodes a functional $\mathrm{Mg} 2+$ transporter. $J$ Biol Chem 2007; 282: 8060-8068.

43. Goytain A, Quamme GA. Identification and characterization of a novel family of magnesium transporters, $\mathrm{MMgT} 1$ and $\mathrm{MMgT} 2$. Am J Physiol Cell Physiol 2008; 294: C495-C502.

44. Goytain A, Hines RM, Quamme GA. Huntingtin-interacting proteins, HIP14 and HIP14L, mediate dual functions: Palmitoyl acyltransferase and Mg2+ transport. J Biol Chem 2008; 283: $33365-$ 33374.

45. Simon DB, Lu Y, Choate KA, Velazquez H, Al-Sabban E, Praga $\mathrm{M}$, et al. Paracellin-1, a renal tight junction protein required for paracellular Mg2+ resorption. Science 1999; 285: 103-106.

46. Schlingmann KP, Weber S, Peters M, Niemann Nejsum L, Vitzthum $\mathrm{H}$, Klingel K, et al. Hypomagnesemia with secondary hypocalcemia is caused by mutations in TRPM6, a new member of the TRPM gene family. Nat Genet 2002; 31: 166-170.

47. Walder RY, Landau D, Meyer P, Shalev H, Tsolia M, Borochowitz $\mathrm{Z}$, et al. Mutation of TRPM6 causes familial hypomagnesemia with secondary hypocalcemia. Nat Genet 2002; 31: 171-174.

48. Nadler MJ, Hermosura MC, Inabe K, Perraud AL, Zhu Q, Stokes $\mathrm{AJ}$, et al. LTRPC7 is a Mg ATP-regulated divalent cation channel required for cell viability. Nature 2001; 411: 590-595.

49. Runnels LW, Yue L, Clapham DE. TRP-PLIK, a bifunctional protein with kinase and ion channel activities. Science 2001; 291: $1043-1047$

50. Clapham DE, Montell C, Schultz G, Julius D. International Union of Pharmacology. International Union of Pharmacology. XLIII: Compendium of voltage-gated ion channels: Transient receptor potential channels. Pharmacol Rev 2003; 55: 591-596.

51. Kraft R, Harteneck C. The mammalian melastatin-related transient receptor potential cation channels: An overview. Pflugers Arch 2005; 451: 204-211.

52. Watanabe H, Murakami M, Ohba T, Ono K, Ito H. The pathological role of transient receptor potential channels in heart disease. Circ J 2009; 73: 419-427.

53. Ando J, Yamamoto K. Vascular Mechanobiology. Circ J 2009; 73: $1983-1992$.

54. Duncan LM, Deeds J, Hunter J, Shao J, Holmgren LM, Woolf EA, et al. Down-regulation of the novel gene melastatin correlates with potential for melanoma metastasis. Cancer Res 1998; 58: 15151520.

55. Grimm C, Kraft R, Sauerbruch S, Schultz G, Harteneck C, Goel M, et al. Molecular and functional characterization of the melastatinrelated cation channel TRPM3. J Biol Chem 2003; 278: 2149321501.

56. Lee N, Chen J, Sun L, Wu S, Gray KR, Rich A, et al. Expression 
and characterization of human transient receptor potential melastatin 3 (hTRPM3). J Biol Chem 2003; 278: 20890-20897.

57. Zhang Y, Hoon MA, Chandrashekar J, Mueller KL, Cook B, Wu $\mathrm{D}$, et al. Coding of sweet, bitter, and umami tastes: Different receptor cells sharing similar signaling pathways. Cell 2003; 112: 293 301 .

58. Earley S, Waldron BJ, Brayden JE. Critical role for transient receptor potential channel TRPM4 in myogenic constriction of cerebral arteries. Circ Res 2004; 95: 922-929.

59. Fonfria E, Murdock PR, Cusdin FS, Benham CD, Kelsell RE, McNulty S. Tissue distribution profiles of the human TRPM cation channel family. J Recept Signal Transduct Res 2006; 26: 159-178.

60. Schmitz C, Perraud AL, Fleig A, Scharenberg AM. Dual-function ion channel/protein kinases: Novel components of vertebrate magnesium regulatory mechanisms. Pediatr Res 2004; 55: 734-737.

61. Perraud AL, Fleig A, Dunn CA, Bagley LA, Launay P, Schmitz $\mathrm{C}$, et al. ADP-ribose gating of the calcium-permeable LTRPC2 channel revealed by Nudix motif homology. Nature 2001; 411: $595-599$.

62. Hara Y, Wakamori M, Ishii M, Maeno E, Nishida M, Yoshida T, et al. LTRPC2 $\mathrm{Ca} 2$ +-permeable channel activated by changes in redox status confers susceptibility to cell death. Mol Cell 2002; 9: $163-173$.

63. Monteilh-Zoller MK, Hermosura MC, Nadler MJS, Scharenberg AM, Penner R, Fleig A. TRPM7 provides an ion channel mechanism for cellular entry of trace metal ions. J Gen Physiol 2003; 121: $49-60$.

64. van de Graaf SF, Bindels RJ, Hoenderop JG. Physiology of epithelial $\mathrm{Ca} 2+$ and $\mathrm{Mg} 2+$ transport. Rev Physiol Biochem Pharmacol 2007; 158: 77-160.

65. Chubanov V, Gudermann T, Schlingmann KP. Essential role for TRPM6 in epithelial magnesium transport and body magnesium homeostasis. Pflugers Arch 2005; 451: 228-234.

66. Chubanov V, Schlingmann KP, Waring J, Heinzinger J, Kaske S, Waldegger S, et al. Hypomagnesemia with secondary hypocalcemia due to a missense mutation in the putative pore-forming region of TRPM6. J Biol Chem 2007; 282: 7656-7667.

67. Voets T, Nilius B, Hoefs S, van der Kemp AW, Droogmans G, Bindels RJ, et al. TRPM6 forms the Mg2+ influx channel involved in intestinal and renal Mg2+ absorption. J Biol Chem 2004; 279: $19-25$.

68. Groenestege WM, Hoenderop JG, van den Heuvel L, Knoers N, Bindels RJ. The epithelial Mg2+ channel transient receptor potential melastatin 6 is regulated by dietary $\mathrm{Mg} 2+$ content and estrogens. J Am Soc Nephrol 2006; 17: 1035-1043.

69. Groenestege WM, Thebault S, van der Wijst J, van den Berg D, Janssen R, Tejpar S, et al. Impaired basolateral sorting of pro-EGF causes isolated recessive renal hypomagnesemia. J Clin Invest 2007; 117: 2260-2267.

70. Thebault S, Alexander RT, Tiel Groenestege WM, Hoenderop JG, Bindels RJ. EGF increases TRPM6 activity and surface expression. J Am Soc Nephrol 2009; 20: 78-85.

71. Ikari A, Sanada A, Okude C, Sawada H, Yamazaki Y, Sugatani J, et al. Up-regulation of TRPM6 transcriptional activity by AP-1 in renal epithelial cells. J Cell Physiol 2010; 222: 481 -487.

72. Schrag D, Chung KY, Flombaum C, Saltz L. Cetuximab therapy and symptomatic hypomagnesemia. J Natl Cancer Inst 2005; 97: $1221-1224$

73. Tejpar S, Piessevaux H, Claes K, Piront P, Hoenderop JG, Verslype $\mathrm{C}$, et al. Magnesium wasting associated with epidermal growthfactor receptor-targeting antibodies in colorectal cancer: A prospective study. Lancet Oncol 2007; 8: 387-394.

74. Cao G, van der Wijst J, van der Kemp A, van Zeeland F, Bindels RJ, Hoenderop JG. Regulation of the epithelial Mg2+ channel TRPM 6 by estrogen and the associated repressor protein of estrogen receptor activity (REA). J Biol Chem 2009; 284: 14788-14795.

75. Li M, Jiang J, Yue L. Functional characterization of homo- and heteromeric channel kinases TRPM6 and TRPM7. J Gen Physiol 2006; 127: 525-537.

76. Jin J, Desai BN, Navarro B, Donovan A, Andrews NC, Clapham DE. Deletion of Trpm7 disrupts embryonic development and thymopoiesis without altering Mg2+ homeostasis. Science 2008; 322: $756-760$

77. Demeuse P, Penner R, Fleig A. TRPM7 channel is regulated by magnesium nucleotides via its kinase domain. J Gen Physiol 2006; 127: 421-434.

78. Yamaguchi H, Matsushita M, Nairn AC, Kuriyan J. Crystal structure of the atypical protein kinase domain of a TRP channel with phosphotransferase activity. Mol Cell 2001; 7: 1047-1057.

79. Penner R, Fleig A. The Mg2+ and $\mathrm{Mg}(2+)$-nucleotide-regulated channel-kinase TRPM7. Handb Exp Pharmacol 2007; (179): 313 328.

80. Matsushita M, Kozak JA, Shimizu Y, McLachlin DT, Yamaguchi $\mathrm{H}$, Wei FY, et al. Channel function is dissociated from the intrinsic kinase activity and autophosphorylation of TRPM7/ChaK1. J Biol Chem 2005; 280: 20793-20803.

81. Dorovkov MV, Ryazanov AG. Phosphorylation of annexin I by TRPM7 channel-kinase. J Biol Chem 2004; 279: 50643-50646.

82. Clark K, Langeslag M, van Leeuwen B, Ran L, Ryazanov AG, Figdor CG, et al. TRPM7, a novel regulator of actomyosin contractility and cell adhesion. EMBO J 2006; 25: 290-301.

83. Su LT, Agapito MA, Li M, Simonson WT, Huttenlocher A, Habas $\mathrm{R}$, et al. TRPM7 regulates cell adhesion by controlling the calcium-dependent protease calpain. J Biol Chem 2006; 281: 1126011270 .

84. Aarts MM, Tymianski M. TRPMs and neuronal cell death. Pfiugers Arch 2005; 451: 243-249.

85. Sahni J, Scharenberg AM. TRPM7 ion channels are required for sustained phosphoinositide 3-kinase signaling in lymphocytes. Cell Metab 2008; 8: 84-93.

86. Joffres MR, Reed DM, Yano K. Relation of magnesium intake and other dietary factors to blood pressure the Honolulu Heart Study. Am J Clin Nutr 1987; 45: 469-475.

87. Kesteloot H, Joossens JV. Relationship of dietary sodium, potassium, calcium, and magnesium with blood pressure: Belgian Interuniversity Research on Nutrition and Health. Circulation 1988; 12: $594-599$.

88. Ascherio A, Hennekens C, Willett WC, Sacks F, Rosner B, Manson $\mathrm{J}$, et al. Prospective study of nutritional factors, blood pressure and hypertension among US women. Hypertension 1996; 27: $1065-1072$.

89. Inoue R, Jensen LJ, Shi J, Morita H, Nishida M, Honda A, et al. Transient receptor potential channels in cardiovascular function and disease. Circ Res 2006; 99: 119-131.

90. Berthelot A, Esposito J. Effects of dietary magnesium supplementation on the development of hypertension in spontaneously hypertensive rat. J Am Coll Nutr 1983; 4: 343-353.

91. Touyz RM, Milne FJ. Magnesium supplementation attenuates, but does not prevent, the development of hypertension in spontaneously hypertensive rats. Am J Hypert 1999; 12: 757-765.

92. Ford ES. Race, education and dietary cations: Findings from the third national health and nutrition examination survey. Ethhnicity Dis 1998; 8: 10-20.

93. Barbagallo M, Gupta RK, Dominguez LJ, Resnick LM. Cellular ionic alterations with age: Relation to hypertension and diabetes. $J$ Am Geriatr Soc 2000; 48: 1111-1116.

94. Laurant $\mathrm{P}$, Berthelot $\mathrm{A}$. Influence of endothelium on Mg2+-induced relaxation in noradrenaline-contracted aorta from DOCAsalt hypertensive rat. Eur J Pharmacol 1994; 258: 167-172.

95. Tammaro P, Smith AL, Crowley BL, Smirnov SV. Modulation of the voltage-dependent $\mathrm{K}+$ current by intracellular $\mathrm{Mg} 2+$ in rat aortic smooth muscle cells. Cardiovasc Res 2005; 65: 387-396.

96. Yamaoka K, Seyama I. Regulation of Ca channel by intracellular $\mathrm{Ca} 2+$ and Mg2+ in frog ventricular cells. Pflügers Arch 1996; 431: $305-317$

97. Gilbert D'Angelo EK, Singer HA, Rembold CM. Magnesium relaxes arterial smooth muscle by decreasing intracellular $\mathrm{Ca} 2+$ without changing intracellular Mg2+. J Clin Invest 1992; 89: $1988-1994$

98. Yang Z, Wang J, Altura BT, Altura BM. Extracellular magnesium deficiency induces contraction of arterial muscle: Role of PI3-kinases and MAPK signaling pathways. Pflugers Arch 2000; 439: $240-247$.

99. Altura BM, Altura BT, Carella A. Magnesium deficiency-induced spasms of umbilical vessels: Relation to preeclampsia, hypertension, growth retardation. Science 1983; 221: 376-378.

100. Kisters K, Barenbrock M, Louwen F, Hausberg M, Rahn KH, Kosch M. Membrane, intracellular, and plasma magnesium and calcium concentrations in preeclampsia. Am J Hypertens 2000; 13: $765-769$.

101. Laurant P, Berthelot A. Endothelin-1-induced contraction in isolated aortae from normotensive and DOCA-salt hypertensive rats: Effect of magnesium. Br J Pharmacol 1996; 119: 1367-1374.

102. Weglicki WB, Phillips TM, Freedman AM, Cassidy MM, Dickens BF. Magnesium- deficiency elevates circulating levels of inflammatory cytokines and endothelin. Mol Cell Biochem 1992; 110: $169-173$.

103. Touyz RM, Pu Q, He G, Chen X, Yao G, Neves MF, et al. Effects of low dietary magnesium intake on development of hypertension in stroke-prone spontaneously hypertensive rats: Role of reactive 
oxygen species. J Hypertens 2002; 20: 2221-2232.

104. Gueux E, Azais-Braesco V, Bussiere L, Grolier P, Mazur A, Rayssiguier Y. Effect of magnesium deficiency on triacylglycerolrich lipoprotein and tissue susceptibility to peroxidation in relation to vitamin E content. Br J Nutr 1995; 74: 849-856.

105. Rao GN, Berk BC. Active oxygen species stimulate vascular smooth muscle cell growth and proto-oncogene expression. Circ Res 1992; 70: $593-599$.

106. Malpuech-Brugere C, Nowacki W, Daveau M, Gueux E, Linard C, Rock E, et al. Inflammatory response following acute magnesium deficiency in the rat. Biochim Biophys Acta 2000; 1501: 91-98.

107. Gilles-Baillien M, Cogneau M. Mg2+ uptake by intestinal brushborder membrane of spontaneously hypertensive rats. Proc Soc Exp Biol Med 1992; 201: 119-124.

108. Gunther $\mathrm{T}$. $\mathrm{Na}+/ \mathrm{Mg} 2+$ antiport in non-erythrocyte vertebrate cells. Mag Res 2007; 20: 89-99.

109. Touyz RM, Schiffrin EL. Activation of the Na+/H+ exchanger modulates angiotensin II stimulated $\mathrm{Na}+-$ dependent $\mathrm{Mg} 2+$ transport in vascular smooth muscle cells from spontaneously hypertensive rats. Hypertension 1999; 34: 442-449.

110. Touyz RM, Yao G. Inhibitors of $\mathrm{Na}+\mathrm{Mg} 2+$ exchange activity attenuate the development of hypertension in angiotensin II-induced hypertensive rats. J Hypertens 2003; 21: 337-344.

111. Touyz RM, Yao G. Up-regulation of vascular and renal mitogenactivated protein kinases in hypertensive rats is normalized by inhibitors of the $\mathrm{Na}+\mathrm{Mg} 2+$ exchanger. Clin Sci (Lond) 2003; 105: $235-242$.

112. Gurney AM. Going with the flow: Smooth muscle TRPM7 channels and the vascular response to blood flow. Circ Res 2006; 98: $163-164$.

113. Paravicini TM, Yogi A, Mazur A, Touyz RM. Dysregulation of vascular TRPM7 and annexin-1 is associated with endothelial dysfunction in inherited hypomagnesemia. Hypertension 2009; 53: $423-429$.

114. He Y, Yao G, Savoia C, Touyz RM. Transient receptor potential melastatin 7 ion channels regulate magnesium homeostasis in vascular smooth muscle cells: Role of angiotensin II. Circ Res 2005; 96: $207-215$

115. Touyz RM, He Y, Montezano AC, Yao G, Chubanov V, Gudermann T, et al. Differential regulation of transient receptor potential melastatin 6 and 7 cation channels by Ang II in vascular smooth muscle cells from spontaneously hypertensive rats. Am J Physiol Regul Integr Comp Physiol 2006; 290: R73-R78.
116. Sontia B, Montezano AC, Paravicini T, Tabet F, Touyz RM. Downregulation of renal TRPM7 and increased inflammation and fibrosis in aldosterone-infused mice: Effects of magnesium. Hypertension 2008; 51: 915-921.

117. Oancea E, Wolfe JT, Clapham DE. Functional TRPM7 channels accumulate at the plasma membrane in response to fluid flow. Circ Res 2006; 98: 245-253.

118. Yogi A, Callera GE, Tostes R, Touyz RM. Bradykinin regulates calpain and proinflammatory signaling through TRPM7-sensitive pathways in vascular smooth muscle cells. Am J Physiol Regul Integr Comp Physiol 2009; 296: R201-R207.

119. Ameen M, Davies JE, Ng LL. A comparison of free intracellular calcium and magnesium levels in the vascular smooth muscle and striated muscle cells of the spontaneously hypertensive and Wistar Kyoto normotensive rat. Ann New York Acad Sci 1991; 639: $550-553$.

120. Adachi M, Nara Y, Mano M, Ikeda K, Horie R, Yamori Y. Intralymphocytic free calcium and magnesium in stroke-prone spontaneously hypertensive rats and effects of blood pressure and various antihypertensive agents. Clin Exp Pharmacol Physiol 1993; 20: $587-593$.

121. Henrotte JG, Franck G, Santarromana M, Frances H, Mouton D, Motta R. Mice selected for low and high blood magnesium levels: A new model for stress studies. Physiol Behav 1997; 61: 653-658.

122. Asai T, Nakatani T, Yamanaka S, Tamada S, Kishimoto T, Tashiro $\mathrm{K}$, et al. Magnesium supplementation prevents experimental chronic cyclosporine a nephrotoxicity via renin-angiotensin system independent mechanism. Transplantation 2002; 74: 784-791.

123. Runyan AL, Sun Y, Bhattacharya SK, Ahokas RA, Chhokar VS, Gerling IC, et al. Responses in extracellular and intracellular calcium and magnesium in aldosteronism. $J$ Lab Clin Med 2005; 146: $76-84$.

124. Fiebeler A, Muller DN, Shagdarsuren E, Luft FC. Aldosterone, mineralocorticoid receptors, and vascular inflammation. Curr Opin Nephrol Hypertens 2007; 16: 134-142.

125. Delva P, Pastori C, Degan M, Montesi G, Brazzarola P, Lechi A Intralymphocyte free magnesium in patients with primary aldosteronism: Aldosterone and lymphocyte magnesium homeostasis. Hypertension 2000; 35: 113-117.

126. Gao X, Peng L, Adhikari CM, Lin J, Zuo Z. Spironolactone reduced arrhythmia and maintained magnesium homeostasis in patients with congestive heart failure. J Card Fail 2007; 13: $170-$ 177 